\title{
Multi-Criteria Analysis Using Remote Sensing and GIS: Insight into Groundwater Potential of the Fissured Aquifers in the Liptako Socle (Southwestern Niger)
}

\author{
Maman Sani Abdou Babaye ${ }^{1 *}$, Karimou Dia Hantchi' ${ }^{1}$ Ibrahim Wagani', \\ Boukari Issoufou Ousmane ${ }^{2}$, Issoufou Sandao²
}

${ }^{1}$ Department of Geology, UMR SERMUG, Faculty of Science and Techniques, Dan Dicko Dankoulodo University, Maradi, Niger ${ }^{2}$ Department of Geology, Faculty of Science and Techniques, Abdou Moumouni University, Niamey, Niger

Email: *babaye.sani@gmail.com

How to cite this paper: Babaye, M.S.A., Hantchi, K.D., Wagani, I., Ousmane, B.I. and Sandao, I. (2021) Multi-Criteria Analysis Using Remote Sensing and GIS: Insight into Groundwater Potential of the Fissured Aquifers in the Liptako Socle (Southwestern Niger). Journal of Water Resource and Protection, 13, 881-899.

https://doi.org/10.4236/jwarp.2021.1311047

Received: September 8, 2021

Accepted: November 26, 2021

Published: November 29, 2021

Copyright $\odot 2021$ by author(s) and Scientific Research Publishing Inc. This work is licensed under the Creative Commons Attribution International License (CC BY 4.0).

http://creativecommons.org/licenses/by/4.0/

\section{(c) (i) Open Access}

\begin{abstract}
In the basement of southwestern Niger, weathering and fractured zones concentrate most of the groundwater. This study focuses on fractured media and aims to identify areas of productivity in this aquifer to improve the region's water coverage. The cartographic approach developed made it possible to establish synthetic maps based on multi-criteria analysis. The hydrogeological parameters selected include fracturing data, drainage system, slope and piezometric level as well as shallow and deep lithology. The choice of these criteria is based on their physical meaning but also on the availability of data. The integration of all the criteria in a GIS allowed to generate maps of recharge and potential productivity of fractured aquifers in the area. The validation of these thematic maps with independent data confirms their utility as reference standards for accessibility for future resource exploitation. Like any spatialization tool, potential recharge maps will provide valuable information about areas where infiltration is more important, and help control and manage risk zoning. The upward evacuation effect is even more prominent along the lineaments, faults or fractures: thus, to avoid possible pollution and to locate the future hydraulic structures, the analysis of the potential recharge zones remains necessary. The potential productivity index map, in addition to the very punctual sites identified by the fracturing study, made it possible to define areas of high potential productivity.
\end{abstract}

\section{Keywords}

Multi-Criteria Analysis, Fissured Aquifers, Productivity, Groundwater Potential, 
Niger

\section{Introduction}

Basement hydrosystems generally correspond to anisotropic discontinuous media with high permeability contrasts [1]. In connection with the identification of sectors and structural heterogeneities that induce a particular hydraulic behavior, several studies have highlighted the existing relationships between drilling productivity and lithology [2] [3] [4]. Furthermore, the terrain features (e.g. topography, slope, fractures and/or hydrography) have been found to be major impact factors that may influence the groundwater storage and flow [5] [6] [7]. Consequently, productive boreholes were implanted according to idealized mapping favorable areas. If only the main supports of the hydrosystem, particularly fractured aquifer system, are integrated and combined with all the ubiquitous characteristics into a single database, one can expect to identify the factors that influence and that are suitable as a model.

Even under arid basement conditions, where the likelihood of successful drilling is low, geospatial techniques have been suggested as an essential part of the further processing of the combined field data, and even more a powerful tool for groundwater resource mapping, prospecting, planning and management [8] [9] [10]. Furthermore, the combination of appropriate survey techniques (e.g. Remote Sensing, Geophysical and Structural Studies) was also ruled out as a major tool to locate fractures under the weathering layers [3] [11]. Clear characterization of the hydrodynamic functioning units along the water bearing discontinuities in parts of the West Africa basement areas allowed to improve the success rate of drilling [7].

In Niger, the joint use of these techniques in large-scale water research is not very well developed. Nevertheless, some local studies, carried out by international and local design offices, have successfully used a photo-interpretation or combined, photo-interpretation-geophysical approach for the implantation of boreholes [12] [13] [14]. In the Liptako geological complex, wells collecting alluvium and weathering zones are thought to have dried up quickly due to the longest dry season [15]. A significant trait identified in altered horizons is their relatively low saturated level, even in humid regions [16]. Further, the cracked basement horizons are of particular importance. Since the connection degree of the different fracturing networks explains the quasi-totality of the flows. Throughout the southwestern Niger, the failure rate of drilling (i.e. a flow lower than $0.5 \mathrm{~m}^{3}$ per hour) is still around 40\% [17]. Despite this limitation, the fissured basement aquifers in Liptako are in great demand to meet the growing water needs of the population. In fact, the region's population is experiencing severe water shortages locally during the long dry season. In addition to quantitative issues, there are problems related to qualitative risks. The most common are those caused by 
levels of contaminants (e.g. nitrates, arsenic, fluorine) above the limits recommended by the World Health Organization (WHO), which force to abandon about $55 \%$ of drilling due to poor quality waters [18]. As a result, semi-arid sub-soils present a major and concomitant challenge in identifying and highlighting the mapping of healthy and productive areas.

Since drilling is becoming increasingly important in the study area, it is therefore imperative for the location to be effective to identify the most favorable areas. Our view is that detailed studies and a multidisciplinary approach will improve our knowledge of the fractured basement environments and open new prospects on the optimization of the drilling failure rate reduction. In this study, we show that multi-criteria analysis can be used to map the groundwater potential zones in fractured aquifer system. In addition, the map of potential recharge areas helps to generate a potential productivity index map of underground aquifers, as well as to optimize the use of available data.

\section{Data and Methods}

\subsection{Setting}

The study area is located at the southwestern part of Niger in the Department of Tera, about $178 \mathrm{~km}$ from Niamey, the national capital (Figure 1) [19]. It extends from latitudes $13^{\circ} 45^{\prime} \mathrm{N}$ to $14^{\circ} 20^{\prime} \mathrm{N}$ of the Equator and from longitudes $0^{\circ} 30^{\prime}$ to $0^{\circ} 50^{\prime}$ East of the Greenwich Meridian (Figure 1). With a total surface area of 900 $\mathrm{km}^{2}$ [17], the study area constitutes the central part of the Dargol river bassin, which is a tributary of the right bank of the Niger River (Figure 1).

The climate is Sahelian with alternating long dry season (October to May), and a short winter season from June to September. Based on meteorological data from 1999 to 2008 , the extreme monthly temperature values range from $15^{\circ} \mathrm{C}$ (January) to $43^{\circ} \mathrm{C}$ (April-May) for an annual average of $29^{\circ} \mathrm{C}$. The most important variations in temperature are observed during the two periods, "cold" and hot, composing the dry season. The relative humidity of the air shows an annual variation of $18 \%$ (March) to $90 \%$ (August). The average annual rainfall at the Téra pluviometric station (Figure 1) is $409 \mathrm{~mm}$ (1999-2008), while the average annual potential evapotranspiration calculated using the Penman method at the same time is $2000 \mathrm{~mm}$ (i.e. five times the annual rainfall). Twenty-five per cent (25\%) of the precipitation comes from high-intensity events [1] that produce rapid flows of the Hortonian type [20] [21]. The rainfall-related flow begins in June-July and ends three months later, for an average flow of $160,106 \mathrm{~m}^{3}$ per year (1964-1994). The shape, orientation and density of the drainage system vary considerably depending on the topography, the roofing material, the nature and the tectonic structure of the bedrock.

With dune cords inherited from the arid Quaternary periods and some isolated hills whose highest points are about $350 \mathrm{~m}$, the refection of the study area is relatively flat. These morphological complexes are cut by koris (i.e. wadis) that are mostly dry which drain water towards depressions (valleys, ponds) during 


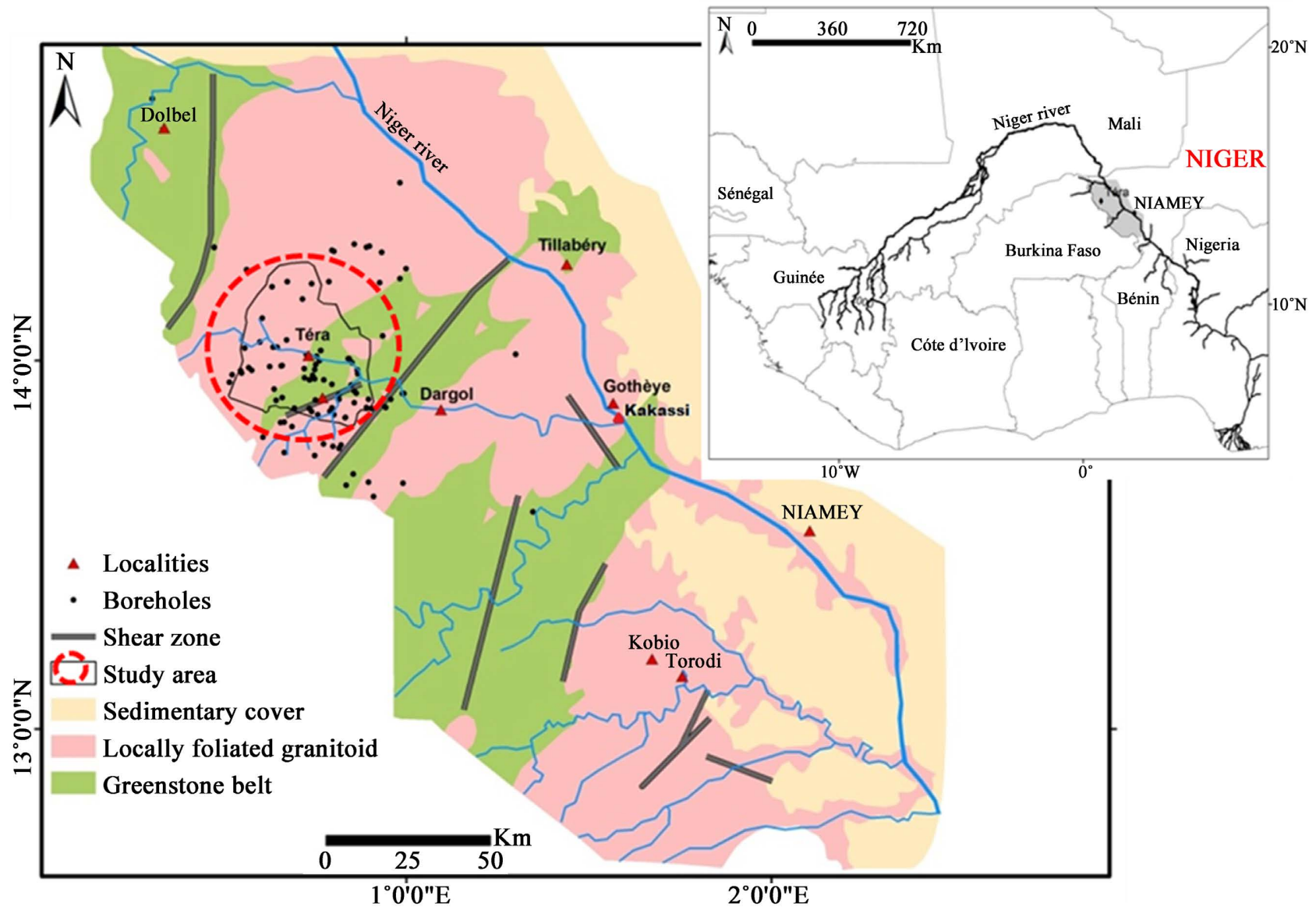

Figure 1. Location and geological context of the study area (Modified from [19]).

the winter season. Degraded and sparse vegetation (savanna and steppe) occupies the plateaus, while lowlands and depressions give way to denser woody vegetation. The growth rate of the local population is about $3.9 \%$ per year over the period 2001-2012, and more than $95 \%$ of the population lives in rainfall agriculture or in extensive livestock farming [22].

The bedrock is made of Precambrian formations, predominantly comprising both alternating granitic intrusive massifs and metamorphic belts (Figure 1). The latter, oriented NNE-SSO, consists of green rocks (pyroxenites, amphibolites, epidotites, chloritoschists, metabasalts, metagabbros), greywackes, rhyolitic tuffs and breccia and various shales [23]. The granitoid intrusions, made up of Eburnean age granites, granodiorites and diorites, contain sometimes relicts of pegmatites and leptynites from the Archean [24]. The subterranean layers and the superficial cover, above the basement formations, include the deep weathering profiles (alterites and soils: 5 to $50 \mathrm{~m}$ thick), the Holocene alluvium and colluvium [25]. Associate major fracture families are mainly structural directions with $\mathrm{N} 20^{\circ}$ to $50^{\circ}$, $\mathrm{N} 60^{\circ}$ to $\mathrm{N} 90^{\circ}, \mathrm{N} 120^{\circ}$ to $\mathrm{N} 140^{\circ}$ and $\mathrm{N} 350^{\circ}$ to $\mathrm{N} 15^{\circ}$ [17]. In crystalline and metamorphic environments, the aquifer zones are located at altered superficial levels (alterites and alluvium) and deep basement levels (cracks and/or fractures). These aquifers are, in many cases, superimposed and form the same aquifer system 
[26]. The upper aquifer, having a capacitive role, is consisted of semi-permeable materials. It overcomes the second level aquifer related to cracks (intermediate zone decompressed), with high permeability forming. Deeper and beneath the second aquifer, lies the third aquifer level in the healthy substratum affected by fractures of tectonic origin (faults). Although generally confined, the deep aquifers of cracked and fractured basements are depleted at the same time with respect to higher horizons.

Thus, the most fractured zones contribute to its essentially conductive function. In this zone, the depth of the water varies according to the topography, the type of aquifer and the seasons. On the other hand, the surface waters still organized around valleys (alluvium) and plateaus (alterites). Water depths range from 1 to $10 \mathrm{~m}$ in traditional wells (i.e. capturing alluvial surface water), while in wells capturing alterites (i.e. modern wells) the water depths are up to 15 or even $30 \mathrm{~m}$ below ground surface.

The prevailing view on the subsurface aquifers, and particularly in Liptako, is therefore that of recurrent problems of water scarcity resulting from their very reactive to rainfall and can dry up during the dry season fluctuations [15]. Deep basement plies are in principle more promising in terms of productivity and sustainability because of the role that fractures play in draining, storing and circulating groundwater. The depth of these holes capturing basement plies varies from 36 to $120 \mathrm{~m}$ with an average of $60 \mathrm{~m}$ and a standard deviation of $20 \mathrm{~m}$. The best flow rates are generally between 30 and $65 \mathrm{~m}$. This is because $76 \%$ of the water inflow is in the first 50 meters, which constitute the upper part of the basement [17]. Beyond this depth, the arrival of water becomes rare or almost absent. On granitic rocks, the depth limit for a good flow rarely exceeds $50 \mathrm{~m}$, whereas it can reach $60 \mathrm{~m}$ and even be slightly exceeded in green rocks (shale). This configuration is believed to be generally explained by the nature and thickness of their weathering products [25] [26].

Lithological diversity and various tectonic phases influence the hydrogeological properties of basement aquifers and of course their productivities. Analysis of the drilling data reveals that the exploitable flows are generally low, ranging from 0.5 to $5 \mathrm{~m}^{3}$ per hour with most of the drilling being limited to values of less than $2.5 \mathrm{~m}^{3}$ per hour. The main finding in such data is that green rocks present higher exploitable flows (average of $2.72 \mathrm{~m}^{3}$ per hour against $1.91 \mathrm{~m}^{3}$ per hour in the granitoids). The greater flows (i.e. more than $10 \mathrm{~m}^{3}$ per hour) are obtained in the drilling carried out at the level of a network of kilometer fractures forming a shearing lane.

\subsection{Database Constitution and Pretreatment}

In this study, data from various sources are used. First, emphasis was laid on obtaining topographic data included two maps (1:200,000; [17]) and the leaves of Sebba and Téra. Then, preferred sampling geological data were Tillabéry and Niamey leaves and geological maps (1:2,000,000; [23]). Piezometric levels data and two complementary scenes of satellite images (Aster, Landsat ETM+) were 
also been selected. The spatial resolution of these images is 30 meters, Digital Shuttle Radar Topography Mission (SRTM).

Pretreatment consisted of georeferencing and mosaicking maps, and images to cover the entire study area. The ENVI 4.3 and PCI Geomatica 9.1 software were used in the processing of satellite images and ArcGis 9.2 for the implementation of the Geographic Information System (GIS) [27]. Additional data, independent of the development of the chosen themes, were included to validate the maps developed. These data concern dry and high-flow boreholes, but also tritium and nitrate contents of boreholes.

The processing of primary data made it possible to generate derived information including slope maps, fracturing densities (lineaments, major fractures) and drainage, then piezometric levels, superficial and deep lithology. The combination of the maps will lead us to the development of potential recharge maps and the potential productivity index.

\subsection{Maps Development}

The methodology adopted for the mapping of potential recharge areas and the potential productivity index of basement aquifers is based on a multi-criteria approach. This process consists of four steps: definition of criteria, classification of criteria, weighting of criteria and combination of criteria.

Both the criteria selected for their influence on the potential recharge zones and potential productivity indices of the aquifers are shown as synthetic flowchart in Figure 2. This list of criteria, particularly important to discriminate between event itself and its consequences, is not necessarily exhaustive. However, given the available data and the hydrogeological and hydroclimatic specificities

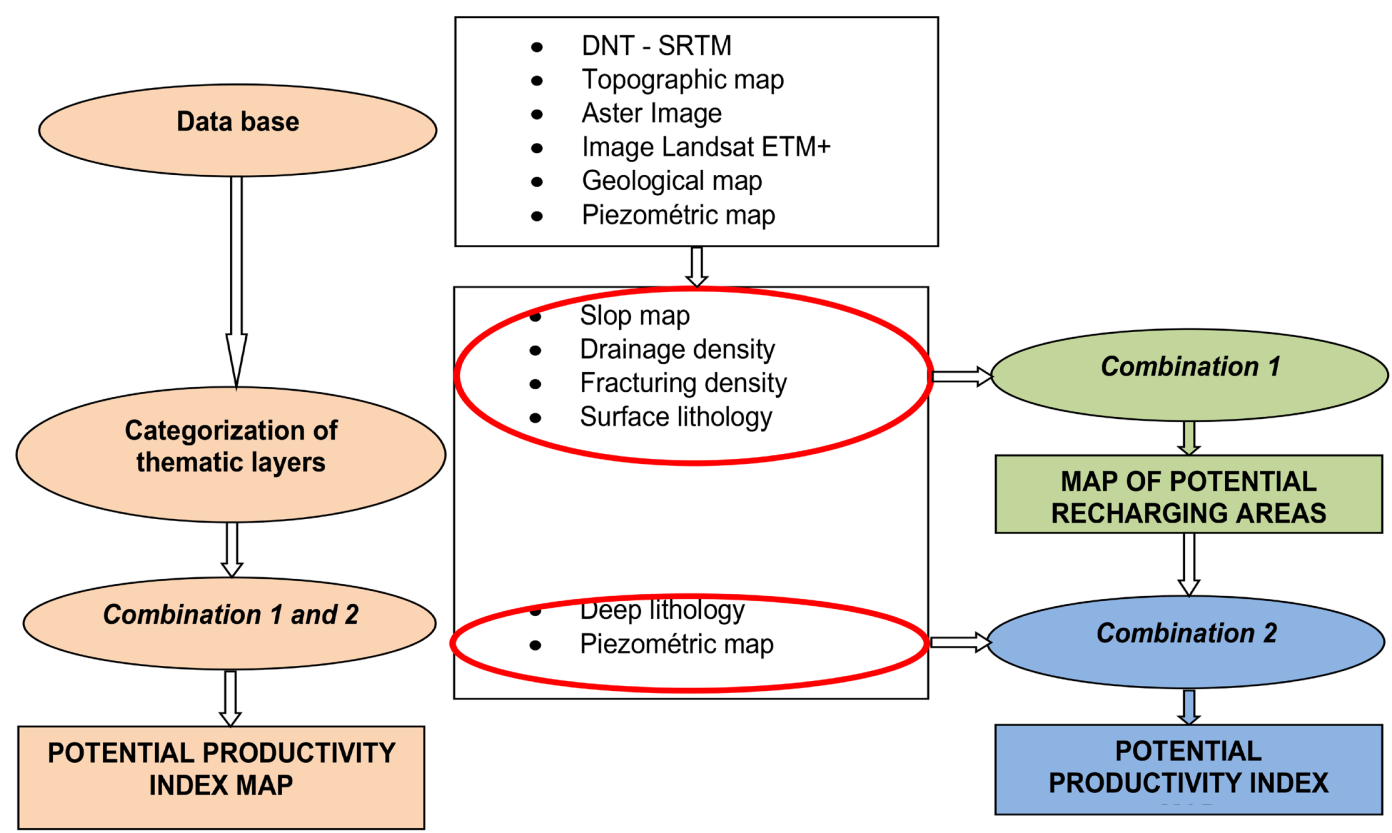

Figure 2. Summary flowchart of the charging card development method and potential productivity index of basement aquifers. 
of the area, the criteria mentioned appear to us to be essential. As a reminder, a multi-criterion methodology is always affected by a certain empiricism and a certain subjectivity [10] [27].

\subsection{Definition and Classification of Criteria}

The objective is to define the realistic criteria used to map the recharge zones and the potential aquifer productivity index in the Dargol basin. The six (6) criteria presented here (Figure 2) are the slope, the drainage and fracturing densities, the piezometric levels, and the shallow and deep lithology.

To facilitate interpretation, each identified criterion is sub-divided into a class ranging from very low to high. The importance of each class varies according to its influence on the subject studied. Thus, all the criteria selected are classified into four classes except the criterion "deep lithology" which has only two classes. We limited the number of classes to two at this criterion, because the study of the rock and productivity of the structures did not allow us to distinguish the role of each facies in the productivity of the structures [17]. This constraint is due to the small number of structures and their concentration at the village level.

\subsection{Assessment, Weighting and Combination of Criteria}

The spatial evaluation of the criteria depends on the theme studied. The achievement of each theme (Potential Recharge Zones and Potential Productivity Index) uses a combination of several criteria (Table 1).

As part of this study, the theme "potential recharge areas" brings together criteria such as slope, shallow lithology, fracturing and drainage densities. For the "potential productivity index" theme, the criteria are the potential recharge zones, the fracturing density, the deep lithology and the piezometric levels.

Multicriteria analysis requires the weighting of the elements according to the importance of each in the realization of the theme. Assigning a weight to a criterion is the most delicate and empirical part of a multi-criteria analysis. It must be done with the overall context of the study in mind. For example, for the realization of the theme "potential recharge zones", the most important "weights" could be assigned to the criteria "fracturing density" and "superficial lithology" by some actors. While for others, the more important are the slope and drainage density criteria. Indeed, they show the very subjective nature of the multi-criteria analysis approach and the role played by the actors in the design and production of realistic maps.

\subsection{Validation}

The different themes of validation are carried out using reference data from field measurements carried out in the catchment works. The data used for this evaluation must comply with the principle of independence [2]. This principle requires that these data have not participated in the development of the map submitted for 
Table 1. Feature classes, codification and weighting of thematic layers of influencing parameters in the study area.

\begin{tabular}{|c|c|c|c|c|}
\hline Themes & Criteria & Classes & Codes & $\begin{array}{l}\text { Weighting } \\
\text { (\%) }\end{array}$ \\
\hline \multirow{16}{*}{$\begin{array}{l}\text { POTENTIAL } \\
\text { RECHARGE } \\
\text { AREAS }\end{array}$} & \multirow{4}{*}{ Slope (\%) } & $<1.5$ & 4 & \multirow{4}{*}{25} \\
\hline & & $1.5-3$ & 3 & \\
\hline & & $3-4.5$ & 2 & \\
\hline & & $4.5-20$ & 1 & \\
\hline & \multirow{4}{*}{$\begin{array}{l}\text { Fracturing density } \\
\qquad\left(30 \times 30 \mathrm{~m}^{2}\right)\end{array}$} & $<0.6$ & 1 & \multirow{4}{*}{25} \\
\hline & & $0.6-1.2$ & 2 & \\
\hline & & $1.2-2$ & 3 & \\
\hline & & $2-4.8$ & 4 & \\
\hline & \multirow{4}{*}{ Superficial lithology } & Bedrock & 1 & \multirow{4}{*}{30} \\
\hline & & Weathered Bedrock & 2 & \\
\hline & & Sand Cover & 3 & \\
\hline & & Alluvium & 4 & \\
\hline & \multirow{4}{*}{$\begin{array}{l}\text { Density of drainage } \\
\qquad\left(30 \times 30 \mathrm{~m}^{2}\right)\end{array}$} & $0-0.25$ & 4 & \multirow{4}{*}{20} \\
\hline & & $0.25-0.5$ & 3 & \\
\hline & & $0.5-0.75$ & 2 & \\
\hline & & $0.75-1.45$ & 1 & \\
\hline \multirow{15}{*}{$\begin{array}{c}\text { POTENTIAL } \\
\text { PRODUCTIVITY } \\
\text { INDEX }\end{array}$} & \multirow{4}{*}{ Potential recharge areas } & $<1.8$ & 1 & \multirow{4}{*}{35} \\
\hline & & $1.8-2.3$ & 2 & \\
\hline & & $2.3-2.7$ & 3 & \\
\hline & & $2.7-4$ & 4 & \\
\hline & \multirow{5}{*}{ Piezometric levels (m) } & $<215$ & 1 & \multirow{5}{*}{10} \\
\hline & & $215-230$ & 2 & \\
\hline & & $230-245$ & 3 & \\
\hline & & & & \\
\hline & & $245-260$ & 4 & \\
\hline & \multirow{4}{*}{$\begin{array}{l}\text { Fracturing density } \\
\qquad\left(30 \times 30 \mathrm{~m}^{2}\right)\end{array}$} & $<0.6$ & 1 & \multirow{4}{*}{20} \\
\hline & & $0.6-1.2$ & 2 & \\
\hline & & $1.2-2$ & 3 & \\
\hline & & $2-4.8$ & 4 & \\
\hline & \multirow{2}{*}{ Deep lithology } & Granitoids & 3 & \multirow{2}{*}{35} \\
\hline & & Greenstones & 4 & \\
\hline
\end{tabular}

evaluation. In the case in point, the data used to validate two topics are the hydrogeochemical and isotopic data for the map of potential recharge areas and 
drilling parameters (operating flow, dry boreholes) for the potential productivity index map.

\section{Results and Discussion}

\subsection{Analysis of the Thematic Maps Generated over the Cartographic and Satellite Data}

\subsubsection{Slope Density Map}

Overall, the distribution patterns of the slopes in the Dargol basin (Figure 3(a)) show results that are clearly consistent with rainwater runs off slopes or steep slopes. This runoff slows when the slope becomes low and the water in the low-slope depressions stagnates while the infiltration takes over the runoff. This criterion then makes it possible to identify the low slope zones indicating the zones favorable to good infiltration conditions. The role played by the slope in the infiltration of water shows the importance of this criterion in the development of the recharge map [5]. The slope map analysis gives indications on the low slope low zones, favorable to the implantation of the drillings. These areas are mainly concentrated in the northeastern parts of Téra, Doumba, Diagorou, Toumbindé and North Sékomé.

\subsubsection{Fracturing Density Map}

In crystalline and metamorphic basement medium, aquifers owe their permeability through cracks [23]. The connectivity of this network of cracks is usually provided by sub-vertical joints. At the level of healthy bedrock, major fractures of tectonic origin give this rock block high permeability and the drilling performed on these fractures usually shows higher flows than elsewhere [6] [11].

Based on this, the very complex role of fractures in the storage and drainage of subsoil groundwater can be taken into account. A lineage density map, derived from satellite image processing, have been generated to discriminate higher and lower permeability basement areas by estimating that this will influence high or low infiltration. With underground transfers and/or preferential zones of underground flow within the basement aquifer, the second aspect is considered.

The fracturing density map (Figure $3(b)$ ) shows the intensity of the deformations experienced by the Dargol basin over time. The North-East zones of Téra, Doumba, Diagorou, Toumbindé and Sékomé North have very high fracturing densities. On the other hand, the areas of Chatoumane, Tondigoungou and almost all of the northern part are at low to very low density. This map gives an idea of the zonal permeability observed in the Dargol basin.

\subsubsection{Drainage Density Map}

In principle, the density of the drainage network makes it possible to evaluate a certain potential for groundwater recharge by surface water. The development of this network is also influenced by the lithological and tectonic nature of the terrain [6]. Numerous authors have combined the lineament density map with the drainage density map to map areas with open fractures [2] [3]. According to [6], 

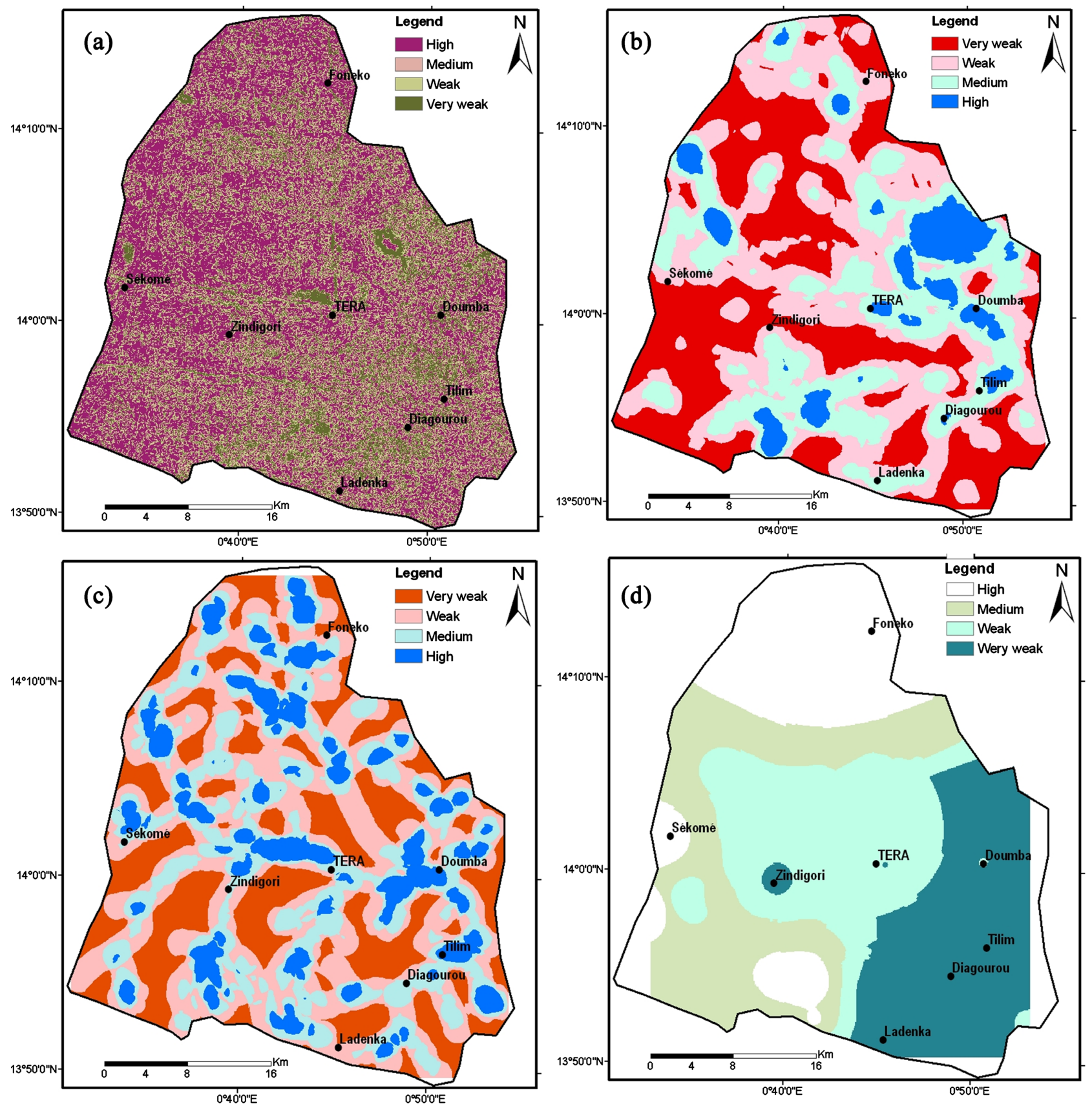

Figure 3. Thematic maps obtained: (a) Slope density, (b) fracture density, (c) drainage density and (d) piezometric levels.

the presence of groundwater is associated with wadi beds because their orientations are controlled by regional fractures.

The drainage density distribution (Figure $3(\mathrm{c})$ ) shows that low density areas are located in the Southwest and Southeast parts. These areas are more developed on the granitoids than on the green rocks. Areas with high and medium density drainage are observed throughout the basin.

\subsubsection{Piezometric Levels Map}

This criterion informs in part on the exploitability of the water table, and to a 
lesser extent on its productivity, because in a fractured bedrock area, the fractures responsible for the flow can be more and more closed with depth. Water level altitudes are shown in Figure 3(d). The domes and decrease of the piezometric levels evolution from upstream to downstream have been observed in the regions of Sékomé, Chatoumane, Toumbindé and Téra. This localized difference in water levels shows that water storage conditions differ from one place in the water table to another. This criterion, combined with others, will give more visibility to the Potential Productivity Index for aquifers.

\subsubsection{Superficial and Deep Lithology Zonation Maps}

The spatial distribution of each lithology (superficial lithology, deep lithology) is highly variable, as shown in Figure 4 for the study area. The importance of localized recharge in semi-arid zones [28] makes it necessary to take this type of map into account in the development of the multi-criteria approach reloading map [4] [10].

Flush rocks significantly affect the infiltration of water to the groundwater (Figure 4(a)). Depending on the size of the space they occupy, we have the sandy cover, the bedrock substratum altered, the alluvium and the flush bedrock. The sandy cover largely occupies the southern part, and also the northern end of the study area. These are the areas where rainfed crops are practiced. The sandy terrain is generally favorable for water infiltration and recharge under certain conditions. The altered Precambrian substratum is mostly developed in the northern half of the region. Some points are observed in South-East, South-West and South-Center. On this encrusted soil, infiltration is reduced, which causes strong runoff from koris to the lowlands.
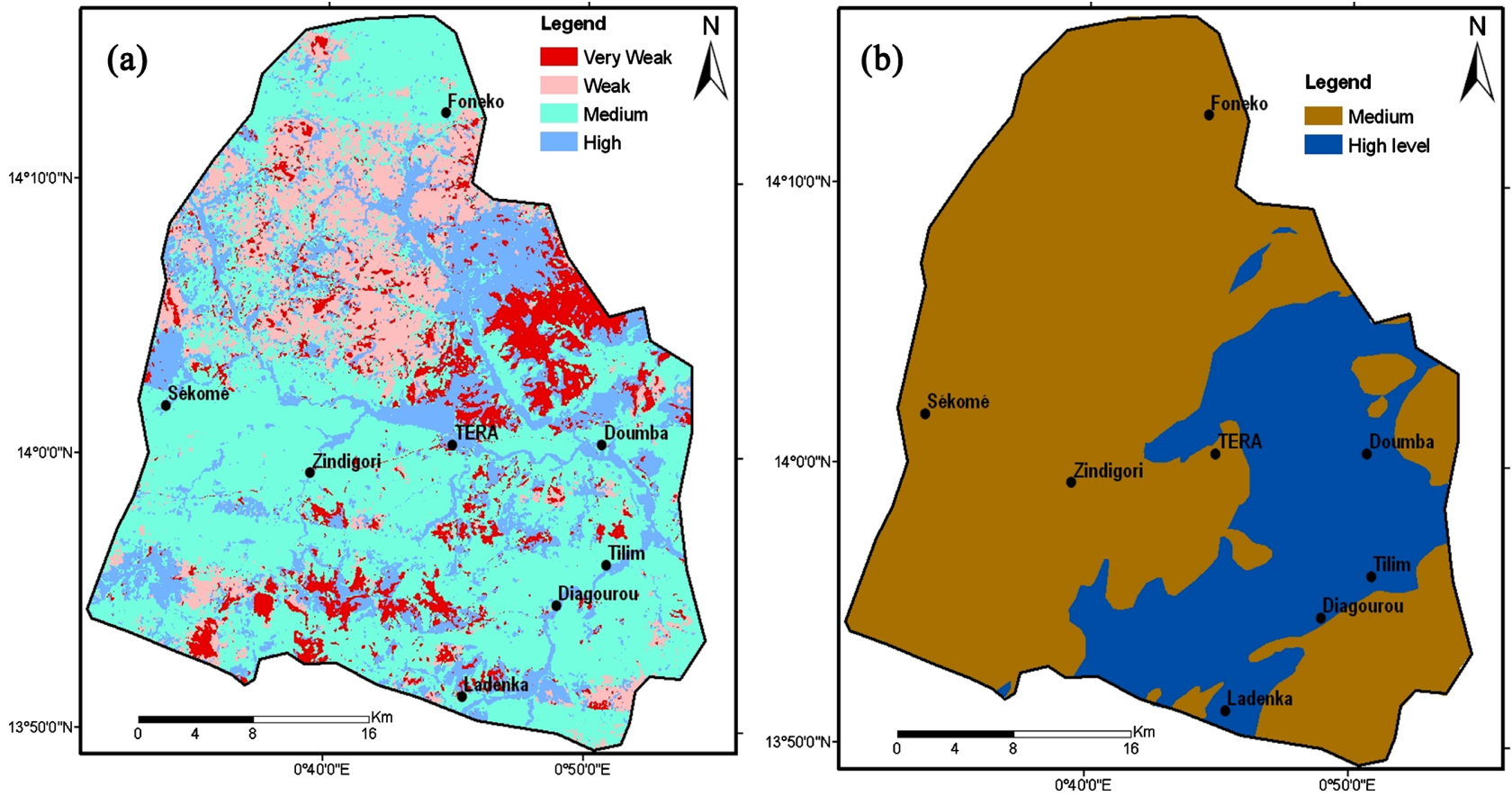

Figure 4. (a) Superficial and (b) deep lithology contour maps in the study area. 
Naturally, the alluvial lands are founding in the bed of koris and alluvial plains. Their distribution does not show any zonal importance of these lands. Nevertheless, some areas such as North Sékomé, North Téra and South Chatoumane have been interpreted and distinguished as an effect of the relatively development of alluvial terrain. The piezometric, hydrogeochemical and isotopic studies carried out in the study area [17] revealed that the alluvial sites constitute the privileged zones of recharge. As a result, this class is an important link on the theme of "potential recharge zones".

In the Northeast Téra and the region of Toumbindé, flush bedrock is more widespread. This type of terrain is almost impervious. Such a hypothesis is attractive, through this brief description of the superficial terrain, we have emphasized the importance of each type of terrain to infiltration. Hence, taking account this criterion can helps to reduce the bias in determining recharge areas, and beyond that, the potential productivity index.

Consideration of this criterion is justified because, as well as the fractures, deep lithology also influences groundwater circulation [4] [5]. The geological units are grouped into two types of terrain (Figure 4(b)) with distinct hydrogeological behavior (e.g. sites in the granitoid terrains and that of the green rocks). Granitoid terrains occupy the majority of the area. The green rocks are only found in the South-East part framed on both sides by the Téra and Tondigoungou massifs.

\subsection{Fractured Aquifers Potential Recharge Zone and Productivity Index Maps}

The data mosaic shows that the study area has four potential recharge areas (Figure 5(a)), namely the very low, low, medium and high potential recharge. Areas of high recharge are located around the city of Téra (Figure 1) and in its northeastern part, the regions of Doumba, Diagorou, Toumbindé, Zindigori, Chatoumane and Sékomé. All these regions are marked not only by a high fracturing density but also by low slopes. Given the interdunal valleys and the ridge of the very wet marshy valleys during the rainy season, the Fonéko area at the northern end belongs to the high potential recharge class. At rocky outcrops and encrusted areas forming the glacis, which are highly developed in both northern and eastern parts, areas of low to very low recharge are observed. These regions are indeed marked by the presence of steep-sided dunes (e.g. North East Sékomé, South Zindigori, East Téra) and granitic outcrops or even green rocks.

In addition to the potential recharge areas, Figure 5 also shows zones of potential productivity index (Figure $5(\mathrm{~b})$ ) at sites where both piezometric levels, deep lithology and fracturing density were delineated. Fortunately, map of potential recharge areas provides information on sites where groundwater could be renewed under normal rainfall conditions. They can also be used to prevent the risk of pollution to better manage groundwater resources [17].

The net result from integrating around potential recharge areas is a possible four potential productivity index zones (Figure $5(\mathrm{~b})$ ). The areas that possesses 

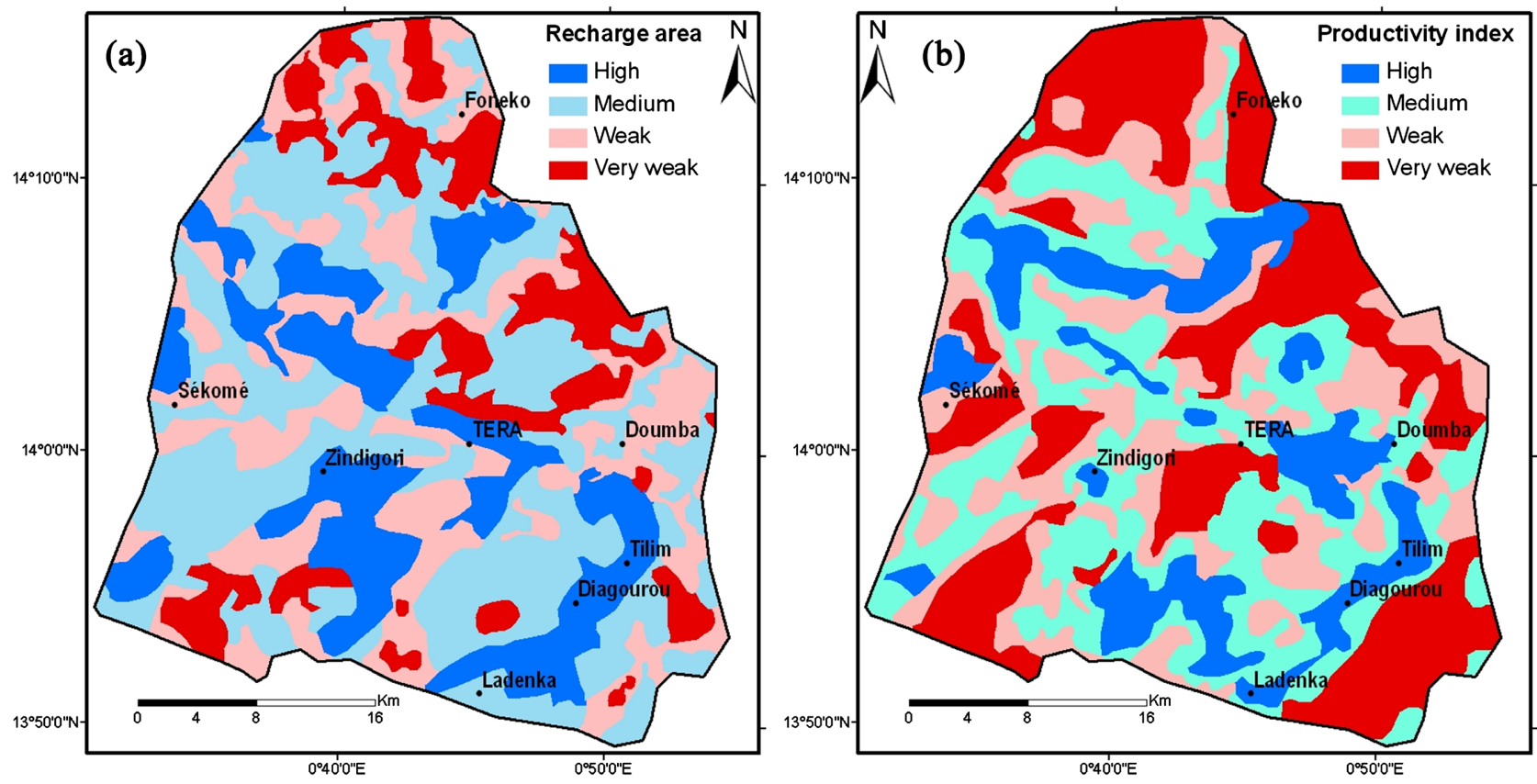

Figure 5. (a) Potential recharge zones and (b) productivity index with the main identified areas of fissured basement aquifers.

the outcrops of granites and points of basic rocks fall within the very low productivity index zone, and matched with very low permeability where infiltration is very difficult. The low potential productivity index areas are located in the North of the region and in the South-West near the Tondigoungou sector. The moderate potential productivity index zone is well developed in the central part, Southwest and Northwest. Generally located on the granite massif topped by sand dunes, those areas depend more on medium fracturing density.

A high potential productivity index zones are concentrated in the southeastern part, particularly the regions of Téra, Doumba and Diagorou. There are also some pockets of these classes in the area of Zindigori, Toumbindé and Sekomé. This class is observed mainly on green rocks, but also at the level of the contact zones. It is also localized on the granitoïdes in particular in the zone of Sékomé and its North-East part. Because they are highly charged, these areas are high index of potential productivity. Fractures are unequivocal zones with very strong permeability favoring infiltration and drainage of groundwater. Therefore, the mapping of these areas is very important in the choice of future geophysical exploration sites [10].

\subsection{Validation of Thematic Maps}

The discontinuous nature and the variability of the hydrodynamic properties make the hydrogeological study of the basement medium very difficult. The probability of success and having a significant amount of water for drilling is determined by several factors, the most dominant of which is fracking (e.g. megafractures and the nodes that they form; [25]).

In this type of context, the validation test of overlaying field reference data 
with thematic maps developed by multi-criteria analysis is very difficult. The difficulty of this test is explained by the fact that this environment always reserves surprise, because next to a high-volume drilling can be a low-flow or dry drilling. It follows that local characteristics (e.g. the presence of sinkholes in the basement [19] or the nature of the veins and their alteration quality [25]) are important. Despite the highly discontinuous nature of this environment, we proceeded to validate by superimposing the tritium contents, nitrates, operating flows and dry boreholes on potential recharge and potential productivity index maps. In doing so, the criterion of independence is respected. Regarding the map of potential recharge areas, the data used relate to tritium and nitrate contents (Figure 6).

The results of the study carried out in this zone have shown that the presence of a certain content of these parameters is synonymous with recent waters, hence the current recharge [17]. Therefore, recent waters will have a tritium content close to, or substantially equal to that of current precipitation (5 UT). The superimposition of tritium contents on the potential recharge chart shows that on 14 boreholes with a high tritium content ( $>3$ UT), 11 drill holes are superimposed on the high recharge classes, i.e. a correspondence rate of $79 \%$ (Figure 6(a)). For low tritium drilling, only Fonéko drilling out of the four is superimposed on the very low recharge class. Yanga drilling, which has a tritium content corresponding to the detection limit $<0.9 \mathrm{UT}$, is located in the high recharge zone. However, the very limited number of low tritium drills does not allow a conclusion on the correspondence within the low recharge class. On the other hand, the correspondence of more than $79 \%$ observed on high to medium sensitivity classes could validate this potential recharge map.
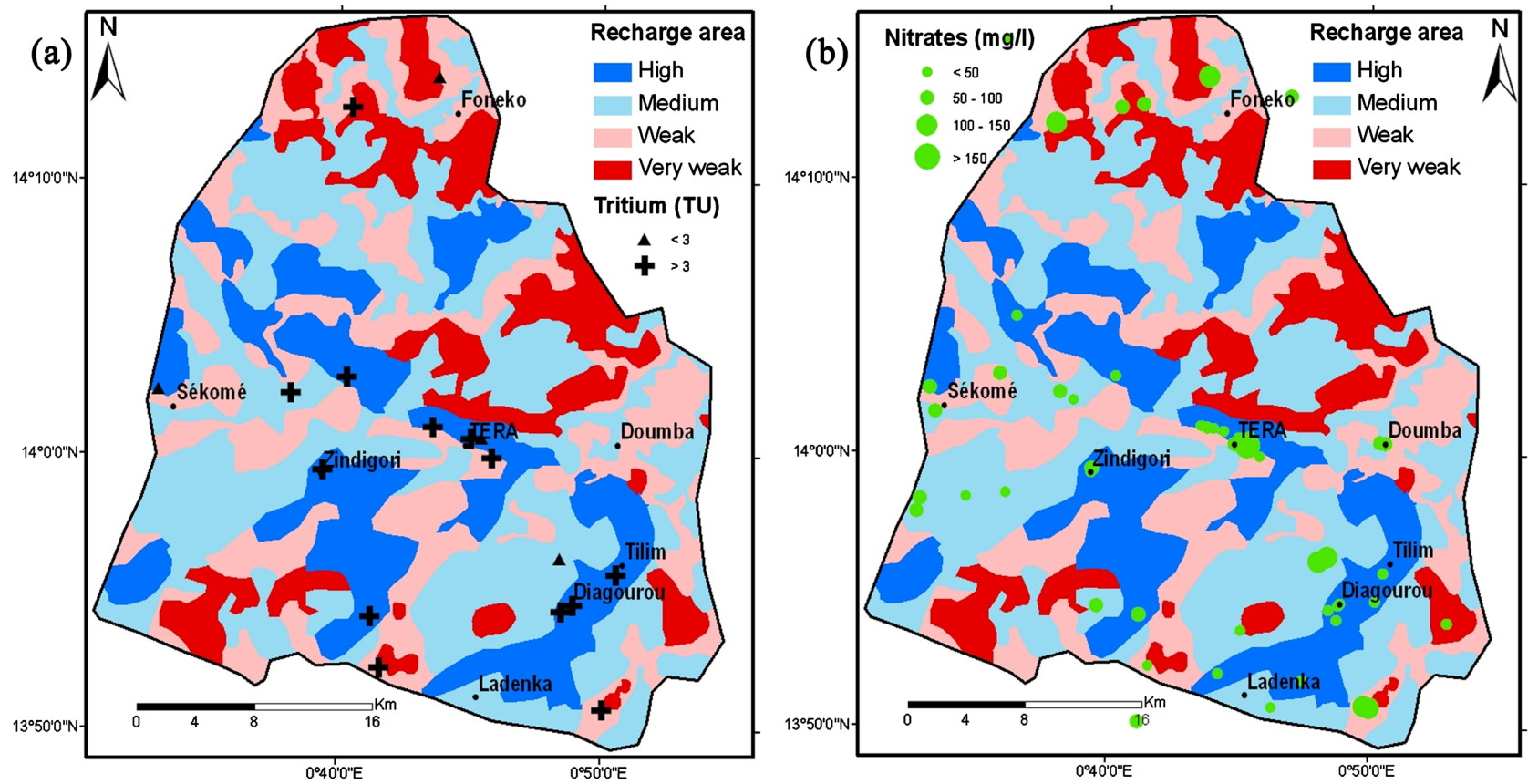

Figure 6. Potential recharge zones relationship with (a) tritium and (b) nitrate concentrations. 
A second validation test was conducted using nitrate levels (Figure 6(b)). It can be seen that of the 22 boreholes with a nitrate content $>50 \mathrm{mg} / \mathrm{l}$, fifteen (15) are located in areas of high or medium recharge, corresponding to a rate of about $70 \%$. The significant degrees of correspondence obtained for these two tests show that the recharge card established by multi-criteria analysis is reliable.

For the validation of the potential productivity index map, we used the drilling operating flow data and the dry boreholes (Figure 7). Indeed, the choice of operating rate for this test is very realistic because it expresses the productivity of the catchment works.

Figure 7(a) shows that the different classes of flow are superimposed to a large extent on the corresponding zones. As a result, $82 \%$ of high-volume structures are superimposed on areas of high and medium productivity. For low flow rates, they can be found in both high and low productivity areas. This is due to the fact that the high productivity of structures in basement areas is very dependent on major fractures. Low-flow drilling is found to be isolated or to secondary fractures. The influence of fractures (fracturing density) on groundwater flow and the productivity of structures has been proven by several authors [6] [29] [30] [31].

Another validity test led us to superimpose dry boreholes on the potential productivity map (Figure $7(\mathrm{~b})$ ). At all, $62 \%$ of the works are located in areas with low or very low productivity, and of the remaining $38 \%$, none of them are located in the area with a high productivity index. These observations further confirm the effectiveness of the approach taken in this work.

\section{Conclusions}

The methodology proposed within the framework of this study made it possible
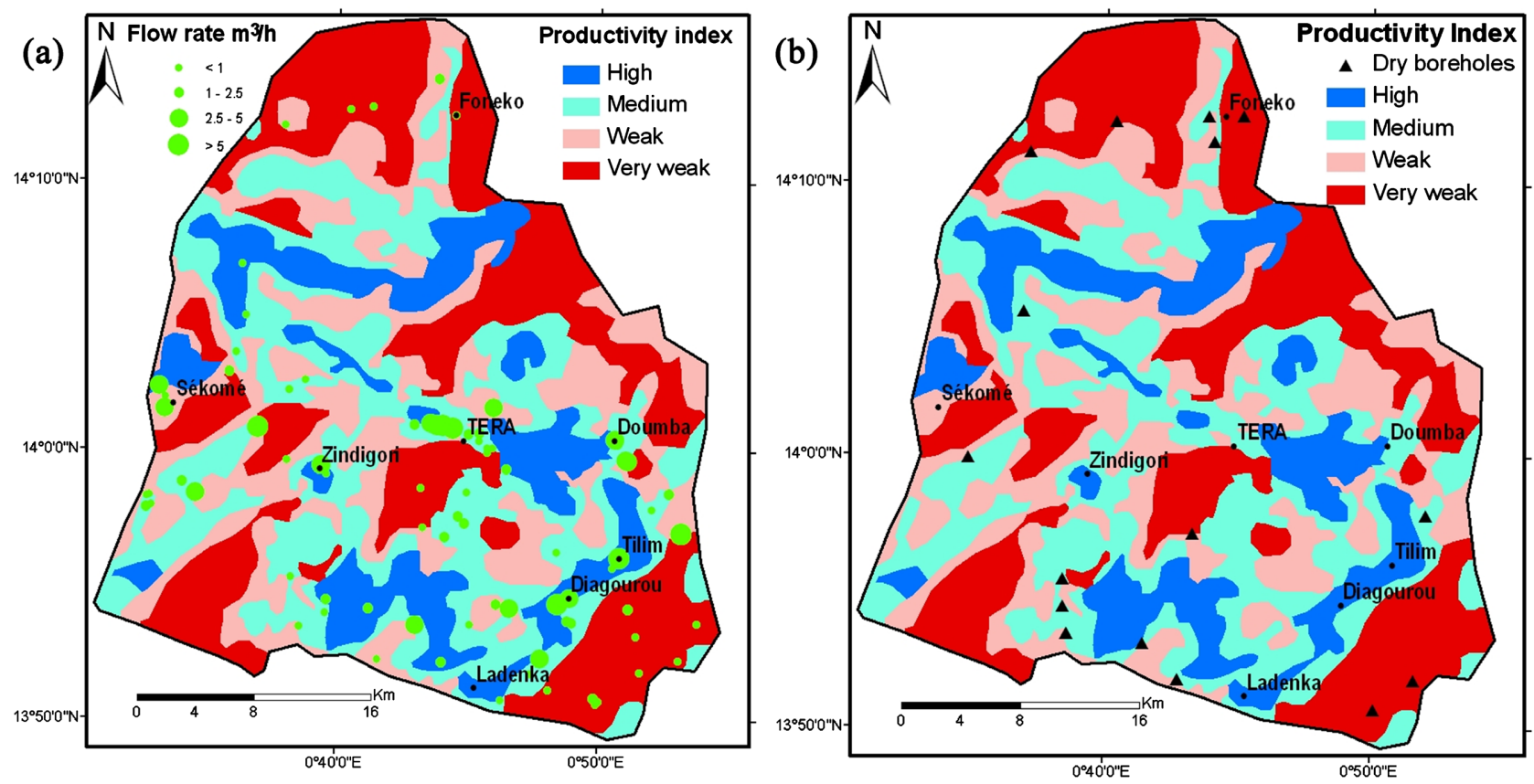

Figure 7. Relation between the productivity index and (a) the production rate, and (b) number of the dry boreholes. 
to develop a specific cartographic model using realistic criteria to express the capacity of the environment to recharge and to circulate groundwater in the fissured zones.

The results obtained from the integrated seven groundwater potential influencing parameters (slope density, fracturing density, drainage density, piezometric levels, land cover, superficial and deep lithology contours) show that the groundwater potential recharge map generated provides information on the favorable recharge zones and serve as a guide for locating future hydraulic structures. The potential productivity index map remains fundamental: it provides insight about areas with high and very low groundwater availability, and possibly topographic and geology effects on presumably recharge. These maps identify the means and tools of knowledge that can be implemented, and define the conditions and important context that ought to be included for a better hydrodynamic modeling of groundwater aquifers.

These results were then validated using quantitative recharge (flow rates and prevalence of dry boreholes) and qualitative (presence of nitrate and tritium as an indicator of certain components of young or old water) control factors. Since independent data can be used to validate thematic maps, it is evident that the potential productivity index map is reliable and useful to guide any future investigations. The dominant use of the potential productivity index map in groundwater research in fissured aquifers of the Liptako could be the selection of productive sites for increased recharge and a tool to assess the impacts of changes in land management practices and land use on water quality.

In addition to very punctual sites, it is appropriate to circumscribe all areas with high potential productivity. The integration of hydrodynamic, chemical et isotopic data with appropriate vulnerability zonation and high probability of drilling success maps is an important step in preventing the risk and danger of contamination in weathered granitoid aquifers in rural southwestern Niger.

\section{Acknowledgements}

This study was carried out thanks to the financial support of the Belgian Technical Cooperation (CTB) and the University of Liège (ULg). It will not be able to come about without the logistical and material help of the Regional Center Agrhymet (CRA), the Ministry of Hydraulics, Environment and the Fight against Desertification (MHE/LCD), and our Professor Ousmane Boureima from Abdou Moumouni University of Niamey (AMU), who unfortunately just passed away. We express our deep gratitude.

\section{Conflicts of Interest}

The authors declare no conflicts of interest regarding the publication of this paper.

\section{References}

[1] Bertrand, C. (2014) Fonctionnement des aquifères hétérogènes: Approche couplée 
de la mesure in Situ et de la modélisation hydrogéochimique pour une compréhension des transferts d'eau souterraine dans les massifs fissurés. Mémoire d'Habilitation à Diriger des Recherches (HDR), Université de Franche-Comté, 98 p. \& Appendices.

[2] Jourda, J.P., Saley, M.B., Djagoua, E.V., Kouame, K.J., Biémi, J. and Razack, M. (2006) Utilisation des données $\mathrm{ETM}^{+}$de Landsat et d'un SIG pour l'évaluation du potentiel en eau souterraine dans le milieu fissuré précambrien de la région de Korhogo (Nord de la Côte d'Ivoire): Approche par analyse multicritère et test de validation. Revue de Télédétection, 5, 339-357.

[3] Jourda, J.P., Kouame, K.J., Saley, M.B., Evrade Eba, L., Anani, A.T. and Biemi, J. (2015) Détermination des zones potentiellement favorables à l'implantation de forages manuels a partir d'analyse multicritère et d'un SIG: Cas de la Côte d'Ivoire. Revue des sciences de P eau, 28, 119-137. https://doi.org/10.7202/1032294ar

[4] Anaba Onana, A.B., Ndam Ngoupayou, J.R. and Mvondo Ondoa, J. (2017) Analysis of Crystalline Bedrock Aquifer Productivity: Case of Central Region in Cameroon. Groundwater for Sustainable Development, 5, 66-74. https://doi.org/10.1016/j.gsd.2017.05.003

[5] Yeh, H.F., Lee, C.H., Hsu, K.H. and Chang, P.H. (2008) GIS for the Assessment of the Groundwater Recharge Potential Zone. Environmental Geology, 58, 185-195.

https://doi.org/10.1007/s00254-008-1504-9

[6] Deyassa, G., Kebede, S., Ayenew, T. and Kidane, T. (2014) Crystalline Basement Aquifers of Ethiopia: Their Genesis, Classification and Aquifer Properties. Journal of African Earth Sciences, 100, 191-202. https://doi.org/10.1016/j.jafrearsci.2014.06.002

[7] Akinlalu, A.A., Adegbuyiro, A., Adiat, K.A.N., Akeredolu, B.E. and Lateef, W.Y. (2017) Application of Multi-Criteria Decision Analysis in Prediction of Groundwater Resources Potential: A Case of Oke-Ana, Ilesa Area Southwestern, Nigeria. Journal of Astronomy and Geophysics, 6, 184-200. https://doi.org/10.1016/j.nrjag.2017.03.001

[8] Chenini, I. and Mammou, A.B. (2010) Groundwater Recharge Study in Arid Region: An Approach Using GIS Techniques and Numerical Modeling. Computers and Geosciences, 36, 801-817. https://doi.org/10.1016/j.cageo.2009.06.014

[9] Abuzied, S.M. and Alrefaee, H.A. (2017) Mapping of Groundwater Prospective Zones Integrating Remote Sensing, Geographic Information Systems and Geophysical Techniques in el-qaa Plain Area, Egypt. Hydrogeology Journal, 25, 2067-2088. https://doi.org/10.1007/s10040-017-1603-3

[10] Shailaja, G., Kadam, A.K., Gupta, G., Umrikar, B.N. and Pawar, N.J. (2019) Integrated Geophysical, Geospatial and Multiple-Criteria Decision Analysis Techniques for Delineation of Groundwater Potential Zones in a Semi-Arid Hard-Rock Aquifer in Maharashtra, India. Hydrogeology Journal, 27, 639-654. https://doi.org/10.1007/s10040-018-1883-2

[11] Abdalla, F. (2012) Mapping of Groundwater Prospective Zones Using Remote Sensing and GIS Techniques: A Case Study from the Central Eastern Desert, Egypt. Journal of African Earth Sciences, 70, 8-17. https://doi.org/10.1016/j.jafrearsci.2012.05.003

[12] Iwaco, B.V. (1983) Projet d'hydraulique villageoise dans la région du Liptako de la République du Niger. Rapport.

[13] Ousmane, B. (1988) Étude géochimique et isotopique des aquifères du socle de la bande sahélienne du Niger (Liptako, Sud-Maradi, Zinder-Est). Thèse Université de Niamey, Niamey, 175 p. 
[14] BRGM (1980) Projet 1000 forages dans les zones du socle de la République du Niger.

[15] Saftner, D.M. (2017) Controls on Groundwater Chemistry in Rural Southwest Niger, West Africa. M.Sc. Thesis, University of Nevada, Reno, 109 p.

[16] Ake, G.E., Kouame, K.J., Koffi, A.B. and Jourda, J.P. (2018) Cartographie des zones potentielles de recharge de la nappe de Bonoua (sud-est de la Côte d'Ivoire). Revue des sciences de P eau / Journal of Water Science, 31, 129-144. https://doi.org/10.7202/1051696ar

[17] Abdou Babayé, M.S. (2012) Évaluation des ressources en eau souterraine dans le bassin de Dargol. PhD Thesis, University of Liège, Liège, 235 p.

[18] Ousmane, B., Galadima, S., Moumouni, A. and Soumana, I. (2012) La qualité physico-chimique des eaux des aquifères discontinus du socle du département de Téra (Liptako, Niger): Impacts sur les taux de desserte en eau potable des populations rurales au sahel. Africa Geoscience Review, 19, 1-16.

[19] Willems, L., Lenoir, F., Levecq, J.-M. and Vicat, J.-P. (1993) Évolution du relief au Niger Occidental: Rôle de la fracturation du socle précambrien et de la formation de pseudo-karsts au sein de la lithomarge et de la couverture sédimentaire. Comptes Rendus de P Académie des Sciences, 317, 97-103.

[20] Panthou, G., Vischel, T. and Lebel, T. (2014) Recent Trends in the Regime of Extreme Rainfall in the Central Sahel. Short Communication. International Journal of Climatology, 34, 3998-4006. https://doi.org/10.1002/joc.3984

[21] Amani, A. and Nguetora, M. (2002) Evidence d'une modification du régime hydrologique du fleuve Niger à Niamey. In: Van Lannen, H. and Demuth, S., Eds., Friend 2002 Regional Hydrology. Bridging the Gap between Research and Practice, IAHS Publication No. 274, Wallingford, 449-456.

[22] INS (2012) Présentation des résultats préliminaires du quatrième recensement général de la population et de l'habitat (RGPH). Institut National de la Statistique (INS), République du Niger, 9 p.

[23] Abdou, A., Bonnot, H., Bory Kadey, D., Chalamet, D., St Martin, M. and Younfa, I. (1998) Notice explicative des cartes geologiques du liptako à $1 / 100000^{\mathrm{e}}$ et $1 / 200$ $000^{\mathrm{e}}$. Ministère des mines et de l'énergie du Niger, Niamey, $64 \mathrm{p}$.

[24] Soumaila, A. and Konaté, M. (2005) Caractérisation de la déformation dans la ceinture birimienne (Paléoprotérozoïque) de Diagorou-Darbani (Liptako nigérien, Afrique de l'Ouest). Africa Geoscience Review, 13, 161-178.

[25] Dia Hantchi, K., Guéro, Y., Ambouta, J.-M.K., Ghaleb, B. and Hillaire-Marcel, C. (2018) Évolution de la couverture d'altération du bassin versant de Kobio (Torodi, Niger) d'après les profils des isotopes de l'uranium et du thorium. Afrique Science, 14, 216-231.

[26] Dewandel, B., Lachassagne, P., Wyns, R., Maréchal, J.C. and Krishnamurthy, N.S. (2006) A Generalized 3-D Geological and Hydrogeological Conceptual Model of Granite Aquifers Controlled by Single or Multiphase Weathering. Journal of $\mathrm{Hy}$ drology, 330, 260-284. https://doi.org/10.1016/j.jhydrol.2006.03.026

[27] Nyeko, M. (2012) GIS and Multi-Criteria Decision Analysis for Land Use Resource Planning. Journal of Geographic Information System, 4, 341-348.

https://doi.org/10.4236/jgis.2012.44039

[28] Youan Ta, M., Lasm, T., Patrice Jourda, J.P.J., Saley, M.B., Miessan, G.A., Kouamé, K. and Biémi, J. (2011) Cartographie des eaux souterraines en milieu fissuré par analyse multicritère. Cas de Bondoukou (Côte-d'Ivoire). Revue Internationale de Géomatique, 21, 43-71. https://doi.org/10.3166/rig.21.43-71 
[29] Dhakate, R., Singh, V.S., Negi, B.C., Chandra, S. and Ananda, R.V. (2008) Geomorphological and Geophysical Approach for Locating Favourable Groundwater Zones in Granitic Terrain, Andhra Pradesh, India. Journal of Environmental Management, 88, 1373-1383. https://doi.org/10.1016/j.jenvman.2007.07.014

[30] Bense, V.F., Gleeson, T., Loveless, S.E., Bour, O. and Scibek, J. (2013) Fault Zone. Earth Science Reviews, 127, 171-192. https://doi.org/10.1016/j.earscirev.2013.09.008

[31] Orban, P., Brouyère, S., Batlle-Aguilar, J., Couturier, J., Goderniaux, P., Leroy, M., Maloszewski, P. and Dassargues, A. (2010) Regional Transport Modelling for Nitrate Trend Assessment and Forecasting in a Chalk Aquifer. Journal of Contaminant Hydrology, 118, 79-93. https://doi.org/10.1016/j.jconhyd.2010.08.008 